\title{
Sustainability of intensive groundwater development: experience in Spain
}

\author{
Emilio Custodio $^{1} \cdot$ Andrés Sahuquillo $^{2} \cdot$ José Albiac $^{3}$
}

\begin{abstract}
Intensive aquifer development is common in arid and semiarid countries. The associated economic and social benefits are great, but management is needed and sustainability has to be analysed in the framework of a sound hydrogeological background which includes recharge as a key term. Recharge under natural conditions may greatly differ from the actual value under groundwater exploitation conditions when the aquifer is connected to surface water bodies or evaporation conditions are modified. Actual recharge is not an aquifer property but is variable depending on groundwater abstraction and its pattern, and changes in surface water-groundwater relationships and other circumstances, such as return irrigation flows, leakages, and activities to artificially modify it. Groundwater plays an important role in nature as it sustains spring flow, river base flow, wetlands, and crypto-wetlands, and the related provision of ecological services to mankind. Therefore, developable groundwater resources and their sustainability have to take into account concurrence and the net benefits of capturing it in a given moment and not in other circumstances, and exchanging groundwater-related nature services for the human use of groundwater. The often large storage relative to annual flow of aquifers implies that aquifer development produces effects that may last decades
\end{abstract}

This article is part of the special issue on Sustainable Resource Management: Water Practice Issues.

\footnotetext{
$\triangle$ José Albiac

maella@unizar.es

1 Professor Emeritus, Royal Academy of Sciences, Technical University of Catalonia (UPC), Barcelona, Spain

2 Professor Emeritus, Royal Academy of Sciences, Technical University of Valencia (UPC), Valencia, Spain

3 University of Zaragoza-CITA, Zaragoza, Spain
}

and even affect upcoming human generations. This new dimension, which has economic and sustainability aspects, is not as important for other water resources. Critical flow thresholds have to be considered for groundwater-dependent ecosystems. This is considered from the point of view of water quantity, which is the dominant aspect under arid and semiarid conditions. However, water quality may be as or more important for humans and for nature services, but this needs a separate treatment. The hydrogeological and socio-economic aspects of aquifer behaviour are presented taking into account the experience drawn from some intensively exploited and economically and socially important aquifers, mostly those in La Mancha, in central Spain, but also other intensively exploited Spanish aquifers. Topdown-down administrative decisions to get a given sustainable have resulted in partial failures, but if action is agreed among stakeholders better outcomes could be achieved. Mixed solutions seem the best approach.

Keywords Groundwater resources · Recharge · Sustainability $\cdot$ Surface-groundwater relationships · Ecological services · Long-term behaviour · La Mancha · Spanish examples

\section{Introduction}

A commonly posed question is how much water can be safely abstracted from an aquifer or aquifer system. This was discussed in the early times of intensive groundwater development in the semiarid and arid areas of central and western United States in the 1920s and later in the 1960s in Israel, mostly considering water quantity. The concepts of safe yield, sustainable yield, and other designations were coined (see Custodio 1976). 
Safe yield was defined by Meinzer (1920) as the aquifer abstraction rate that can be permanently done to get water suitable for human uses. Conkling (1946) defined the safe yield as the average mean yearly flow that can be artificially abstracted from an aquifer without producing negative effects. Young (1970) and Visscher (1968) took into account the negative effects, mostly those related with water cost and some environmental impacts. In the ASCE (1961) manual on groundwater management and in later revisions, the concept of sustained yield was introduced, which depends on actions on the aquifer. Bear and Levin (1967) developed the concept of optimal yield, which derives from the optimization of an objective function involving both hydrologic and economic conditions. At the same time, the poorly defined concept of over-exploitation (overdraft) started to be used, mainly by non-hydrogeologists and the media, mostly focusing in the negative aspects (Custodio 2002). Over-exploitation was introduced as a legal term in the Spanish Water Act of 1985.

What is hereinafter presented deals mostly with direct authors' experience. First, the need of defining groundwater resources is dealt with, followed by some definitions of concepts and the meaning of aquifer recharge and water resources from the quantity point of view, taking into account environmental issues. Afterwards, economic and social aspects are introduced. The hydrological conditions and the economic and administrative aspects in the La Mancha (Central Spain) large aquifers follow, with brief comments on other intensively developed Spanish aquifers. Finally, some general conclusions, useful for other areas, are given.

\section{General hydrogeological and groundwater resources issues}

Quantification of groundwater resources is required by water authorities as key values for water planning. However, available groundwater resources are not a fixed value as they depend on actual recharge and discharge and not only on aquifer behaviour under natural conditions. Besides, evaluation results from often quite uncertain values. An aquifer or aquifer system has not a unique value of groundwater resources. This value depends on conditions. A part of them are external and refer to environmental and legal restrictions, social considerations and political constraints. In addition, they refer to decisions relative to the alternative uses of aquifers relative to water storage and distribution, the different possible operation strategies, and the interaction with other water sources and demands.

The following definitions are proposed to clarify terminology and are used hereinafter: a. Groundwater reserves: water volume in the aquifer or aquifer system when aquitards are included. The dynamic reserve is that existing above the lowest drainage point, which exists only if there is recharge. The dead reserve is what remains. However, this distinction is quite artificial as groundwater flow is through the full aquifer thickness.

b. Intensive groundwater exploitation: when natural aquifer functioning and its relationships with other water bodies are significantly modified.

c. Groundwater mining: a large groundwater reserve depletion which needs at least some decades to recover after ceasing groundwater exploitation. It is often difficult to know if abstraction exceeds or not actual recharge.

d. Aquifer recovery time: time needed to approach natural aquifer conditions after ceasing exploitation. In wellrecharged, small sized, and high hydraulic transmissivity aquifers, this time may be months to a few years, but often, it is decades to centuries, depending on the ratio of reserve depletion to actual recharge under recovery conditions.

e. Renewal time: ratio of reserve volume to actual recharge. It is practically equivalent to aquifer turnover time.

f. Groundwater resources: water flow that can be used from a given aquifer after meeting hydrological, environmental, economic, legal, administrative, and social conditions. An average value is adequate to characterise long renewal time aquifers in which the fluctuation of reserves acts as a regulator, but for short renewal time aquifers, a yearly value may be needed.

g. Uncertainty: the fact that the values of magnitudes and variables are not accurately known. This is due to unavoidable stochastic components on any spatial and time scale, and to non-essential uncertainties, which generally dominate. These last are due to insufficient knowledge, inaccurate data, and inadequate conceptual models.

Aquifer development (exploitation, abstraction) implies changes in natural groundwater flow. They become significant and even dominant when development is intensive. The primary effect is groundwater head drawdown, which is accompanied by reserve depletion. The associated changes evolve slowly, depending on the hydraulic properties of the aquifer and its size (Konikow and Leake 2014; Custodio 2002, 2012a). The groundwater level drawdown is hydraulically needed to convey (capture) part of recharge to the abstraction points.

Any exploitation of an aquifer, even if not intensive, produces a water reserve and aquifer outflow reduction. Initially, groundwater abstraction uses aquifer reserves, 
groundwater level drops, and the drawdown cone grows inducing spring and stream flow depletion. After a transient period, aquifer levels stabilize, if abstraction is less than actual recharge. The decrease in spring and surface flows, known as capture, tends asymptotically to equal the flow abstracted. The time to depletion been equal to a given percent of abstraction depends on aquifer storage and the distance from wells to the streams. An approximation of the groundwater volume stored above the outflow point is often one to two orders of magnitude the average annual recharge volume. The ratio of reserve to annual recharge volume increases with the size of the aquifer and also does the time to stabilization.

There are a series of negative externalities linked to groundwater development, such as reduction of spring flow, river base flow, and the size of wetlands fed by groundwater, although evapotranspiration decreases. Other externalities are the destruction of aquatic habitats and land subsidence (Richey et al. 2015).

When groundwater mining happens and is legally, economically, and socially admissible, it should be considered in water planning as a component of integrated water resources management (IWRM) and a subject of good governance. When part of the aquifer water storage is substituted by saline water, as is the case of increasing seawater intrusion in coastal aquifers, total groundwater mining may be small.

Hereinafter, the concepts of groundwater recharge, discharge, resources, reserves, and exploitation are developed from the hydraulic point of view, and also considering the environmental, economic and social points of view. The emphasis is in arid and semiarid areas.

\section{Recharge, discharge, and aquifer behaviour}

Total aquifer recharge is the water flow entering the aquifer through its top as the result of rainfall, snowmelt, stream infiltration and lake loses, and direct and indirect artificial actions. Net recharge is total recharge less loses from the water table by evaporation and transpiration and water returned to the surface as close-to-diffuse outflows in the case of numerous and densely distributed small springs, rivulets, and wetlands.

Rainfall recharge depends on soil and vegetation characteristics. It is related to pattern, time and intensity of precipitation, and on snow cover. In many aquifers in arid or semiarid areas, groundwater recharge depends heavily on runoff infiltration in losing river reaches or in alluvial fans.

Aquifer discharge is outflow to springs, the gaining sections of the streams, the sea, and lake shores, and by evapotranspiration in wetlands. The variability of rainfall and other forms of recharge is buffered by the often large water storage in the aquifer, so discharge is less variable and in large aquifers is almost constant. Artificial discharge is drainage produced by drains, tunnels (galleries), mines and flowing boreholes, and abstraction from wells and boreholes.

Both aquifer recharge and discharge under natural conditions or under given conditions in a reference moment are modified by aquifer development. When there is no river water coming from outside the area and surface water flows and surface water depend only on aquifer discharge, groundwater head drawdown does not significantly affect natural recharge, as it often happens in arid and semiarid conditions, At most, groundwater water level lowering reduces aquifer water loses by evapotranspiration in shallow water table areas. In the case of coastal aquifers, conditions are more complex as freshwater resources are the subject, instead of total water.

Due to groundwater level drawdown, gaining rivers can be transformed into losing rivers or ephemeral stretches. Runoff water in the area may now recharge the aquifer. Dams can increase or decrease aquifer recharge in losing downstream stretches of the river channel because of changes produced in river flows. Recharge from losing streams can also decrease as a result of water diversions upstream. Groundwater recharge can be increased by losing reservoirs.

In agreement with what has been said, considering average terms, there is a natural recharge, or a reference recharge under some well-defined conditions, and an actual recharge which depends on exploitation circumstances and artificial action to modify recharge. Actual recharge is time variable. Therefore, provided recharge values need explanation on their circumstances, including groundwater abstraction and distribution, river flow regime and dam operation. It is not a fixed value, although it is commonly assumed constant by many water managers and planners. A fixed value may be acceptable in mountainous areas but nor in flat areas with a dense river network and shallow water tables.

The exchange of groundwater among aquifers is often not considered recharge or discharge but a separate term of the groundwater balance of each aquifer. When integrating them, double accounting has to be avoided.

Uncertainty can be diminished with improved effort, but there is a limit to what can be reasonably done on technical and economic grounds. In some point, the cost of correcting and compensating epistemological mistakes is less than the cost of improving knowledge and implementing results. Uncertainty of the different terms combines and the resulting recharge error may exceed the recharge value, even if calculated at daily level (Custodio et al. 2015). Environmental, economic, and social data and processes are also quite uncertain. Uncertainty should be made explicit, 
although it is rarely done. This is something not clearly understood by water planners, policy makers, and the society, which ask for well-defined figures. They often consider that giving ranges is the result of poor knowledge. Therefore, data to be supplied have to be adequately presented and should include a security range.

\section{Groundwater resources quantity and their sustainability}

Equating aquifer sustainable groundwater resources-often called renewable groundwater resources - to recharge, as often done, is erroneous due to different reasons:

a. groundwater plays an important role in nature, is essential to many ecological functions, and provides ecological services of economic and social relevance. Therefore, a part of groundwater flow has to be preserved to maintain a fraction of the natural values,

b. groundwater discharge into the sea is needed to limit the saline intrusion and contamination of continental groundwater, laterally and/or by saline up coning. Some outflow to the sea has to be maintained,

c. when the water level lowering exceeds the minimum discharge level, wells cannot sustain their yield in the long term,

d. the pumping depth may become too large (new costly wells and increased energy expenses) and, in some cases, may mobilize saline and low-quality water in some parts of the aquifer, and

e. other water resources in use, such as spring flow and especially river base flow, have to be maintained in some moments of the year.

Aquifer development is a source of considerable damage to wetland ecosystems, the important ecosystem services they provide to mankind, such as provisioning, regulating, cultural and supporting services, and their key role in supporting biodiversity, soil formation, and nutrient cycling (De la Hera and Villarroya 2013; De la Hera et al. 2016; Camacho et al. 2015; Manzano et al. 2015; Bocanegra et al. 2016).

These are some of the reasons by which aquifer abstraction has to be less, sometimes much less, than actual recharge under exploitation conditions. Actual recharge may be different-generally greater-than recharge under natural conditions, especially in arid and semiarid areas. Thus, the sustainably developable amount of groundwater is a fraction of recharge under exploitation conditions. How much is this fraction is not a technical answer as it depends on decisions on whether the effects of aquifer development are bearable and up to which extent. This is a social decision through economic, policy, and political mechanisms, under existing legal and administrative constraints and subjected to ethical and moral considerations.

The full picture as well as the time dimension has to be introduced in deciding the developable groundwater resources. This is especially important for mid- to largesize aquifers, as changes induced by abstraction variations often appear long-delayed. In many cases, water developers, managers, planners, authorities, and politicians are not aware or plainly ignore this, as the main concern is present time. Introducing the long-term time dimension can be done through a social discount rate. This social discount rate value is controversial and besides it is a partial consideration of a complex situation in which direct economic values are accompanied by important externalities and intangibles, further to poor experience and lack of sensitivity. In this context, sustainability becomes not well-defined (Rogers et al. 2004).

Social considerations are often more important than hydrological and hydrogeological ones. However, hydrological knowledge and hydrogeological knowledge are at the basis of any reliable evaluation and action, taken in the framework of integrated water resources (Martínez-Santos et al. 2014; López-Gunn et al. 2011). This involves considering a wider socio-economic context of natural and human resources use, after downscaling facts to the detailed circumstances of a given problem, including the subsidiarity principle for management. This also includes combining the advantages of different water sources to improve water availability by conjunctive use, which include combined and alternate use. Environmental requirements have to be integrated.

Good governance is the key to "sustainable" exploitation of aquifers. Groundwater governance is complex, still poorly experienced, often not supported by adequate legislation, and sometimes unpalatable to old fashioned water administrators and narrow-minded politicians. Governance has to be supported by adequate scientific knowledge and good monitoring, but also needs mechanisms to obtain agreements by all groups involved and to assure that they are honoured, besides a responsible water administration.

Groundwater sustainable development is not the dominant goal when groundwater is part of IWRM. The goal is taking full advantage of the special characteristics associated with the large water storage relative to recharge rate, in combination with surface water conjunctive use and also the other recently incorporated water resources, such as seawater desalination, saline groundwater de-brackishing, and treated wastewater reclamation. They are sometimes called industrial water. In this case, sustainability refers to the water system and also to energy, food and land resources, and to human employment. The large aquifer water storage helps in mitigating droughts and some 
possible future climatic scenarios, through the appropriate use of the storage. Monitoring and studies are the basis to sustainable groundwater development, and modelling is the appropriate decision tool.

Sound aquifer use may involve groundwater mining, even if it is not sustainable in the mid- or long-term. Thus, storage depletion should be part of good governance. It should not be rejected as a principle if it promotes social progress for some time, negative results are adequately compensated, the remaining water storage allows for the transition toward a new water use paradigm, and this does not imply disturbance of economic relationships with other areas. In this case, "sustainable" development may temporarily exceed actual recharge.

\section{Economic and social constraints in groundwater resources evaluation and their sustainability}

The economics of groundwater resources evaluation and management deals with the efficient allocation of groundwater between sectors (including the environment), locations, and time periods. Groundwater economics can be used to address the important undertakings faced by the current management practices around the world. One is the allocation of groundwater stocks and flows to the environment, which provides support to ecosystems and the derived services. The other one is the temporal allocation of groundwater to buffer shortages in surface water, which could become critical during drought periods.

The optimal allocation of groundwater is obtained from a dynamic optimization problem which maximizes the present value of the stream of benefits along the planning horizon. The optimal allocation solution is found when the marginal benefit of extracting water is equal to the marginal opportunity cost. The marginal opportunity cost has two components: the current marginal pumping cost and the future marginal user cost from additional current extractions. The marginal user cost is the reduction of future discounted net benefits incurred from additional current extractions. Future net benefits are reduced, because current extractions increase abstraction costs and decrease benefits in subsequent periods. One example is the reduction of environmental benefits caused by the gradual drawdown of the aquifer water table (Feinerman and Knapp 1983; Qureshi et al. 2012).

The application of groundwater economic principles would be more straightforward if water was a private good traded in markets. However, the evaluation of groundwater resources and its sustainable management is quite challenging, because water is needed for life, its adequate availability is a human right, and water provides goods and services. These goods and services can be classified as private goods, common pool resources, and public goods, depending on the degree of exclusion and rivalry in consumption. Goods are non-excludable when individuals cannot be excluded from use. Goods are non-rival when the use by one individual does not reduce the availability to others. Treated drinking water in urban networks is close to a private good (rivalry and exclusion), and water in streams and aquifers is close to a common pool resource (rivalry and non-exclusion), while water sustaining ecosystems comes close to a public good (non-rivalry and non-exclusion) (Booker et al. 2012). Water management is governed by public policies, because pure competitive markets fail to account for the common pool and public good characteristics of water.

Economic theory describes three types of policy instruments that could account for the market externalities created by the common pool and public good characteristics of water: (1) the "Pigou solution", which is based on taxation of water extractions; this is the approach behind the European water policies (EC 2012); (2) the "Coase solution", which is based on privatizing the resource and trading; this is the water market approach that has been implemented in Australia; and (3) the common property governance advocated by Ostrom $(1990,2010)$ and based on the evidence that coercive government rules fail; this is the institutional approach, where stakeholders themselves have to design the rules and enforcement mechanisms. In countries such as Spain, water management is mostly based on the institutional approach, with stakeholders cooperating with basin authorities. However, mainstream present water policies derive from the Dublin Statement on Water, which declares water an economic good. These policies are mostly grounded on market-based instruments, such as water markets and water pricing. The legal and administrative conditions play an important role in evaluating water resources and establishing their sustainability.

\section{Experience in Spain and legal and administrative constraints}

Groundwater is abstracted in Spain since the late nineteenth century, but its intensive development was mostly produced in the period 1960-1980, depending on the area. Currently, about $7 \mathrm{~km}^{3} /$ year are abstracted, the $75 \%$ for crop irrigation. Some areas depend exclusively on groundwater for supply and irrigation, especially in the Mediterranean area and in the Balearic and Canary archipelagos. Intensive exploitation includes groundwater mining, with an estimated cumulated reserve depletion at about $15 \mathrm{~km}^{3}$ in the south-eastern Iberian Peninsula and $2 \mathrm{~km}^{3}$ in two of the Canary Islands (MASE 2015; Custodio et al. 2016a, b).

The 1985 Spanish Water Act declared all waters a public domain, but allowed existing private groundwater rights 
derived from the 1879 Water Act to continue in the case that right holders did not exchange their rights for a concession of public water (Molinero et al. 2011). As most right holders at the time, when most of the development was done, decided to keep their previous status, in practice, a large part of groundwater rights remain private. The incorporation of Spain to the European Union in 1986 forced readjustments in the Spanish Water Act to transpose the European Water Directives, especially the Framework Directive of 2000 and the so-called Groundwater Daughter Directive of 2006.

To try to solve the problems derived from the intensive aquifer exploitation of many aquifers, the Water Act of 1985 introduced the possibility of declaring an aquifer as "overexploited", with the formation of a groundwater users' association and a compulsory management plan for each aquifer. Only a few recent accomplishments exist, forced by providing highly subsidized imported or desalinized water. Under these conditions, the sustainable use of groundwater cannot be defined, as subsidies may be temporary and distort investment decisions in water development, the improvement of water use efficiency, and the evolution toward a new paradigm in water use. Better results have been obtained through bottom-up groundwater users' associations. The first one was created in 1975 in the Lower Llobregat area. Now, about 20 associations exist.

Water planning was introduced in the Water Act of 1985, and currently, it is a requirement of the European Water Framework Directive. District Water Plans have to define the sustainable use of aquifers, taking into account the relationships with surface water and the preservation and possible restoration of environmental conditions. The important social role and slow time evolution of aquifers are non-adequately considered.

The fact that a large part of groundwater rights remain private should not hinder groundwater management if private rights can be forced to serve the common good. However, this has not been addressed in practice. Management action is mostly done by increasing, often subsidized water offer by public entities, while water demand management is poorly considered.

Groundwater trading has been practiced and is still possible in the case of private water rights. This is of secondary importance, except in the Canary Islands, where it is widely done. Formal water trading of public water is possible after the current Water Act, but under strict control of the public water administration. It refers mostly to deals for importing surface water to south-eastern Spain from outside the area. Water trading affects groundwater exploitation sustainability.

In the following sections, two main cases in the same area are presented, followed by comments on some important aquifers in Spain.

\section{The La Mancha area}

\section{Introduction}

La Mancha is a large, relatively flat area in the southern highlands of central Spain. It is bounded by moderately high hills. Rivers leave the area through slightly encased valleys. The western and central part discharges through the (lower) Guadiana River toward the Atlantic Ocean and the eastern part through the Júcar River toward the Mediterranean Sea, near Valencia (Fig. 1). It is located in the Castilla-La Mancha Region.

La Mancha has a semiarid climate, with important drought periods. It holds some of the largest carbonate aquifers in Spain. What is here presented refers to the Western La Mancha aquifer system (WLMA) and to the Eastern La Mancha aquifer systems (ELMA). The hydrogeological characteristics are presented first and afterwards the relevant socio-economic issues. Subsequently, results are compared.

\section{The Western La Mancha aquifer system (WLMA) and Las Tablas de Daimiel (TD) wetlands}

The Upper Guadiana Basin, till El Vicario reservoir (Fig. 1), extends over $16,130 \mathrm{~km}^{2}$ and holds the WLMA, covering $5500 \mathrm{~km}^{2}$ (Cruces and Martinez-Cortina 2000; Martínez-Cortina et al. 2011). There are more than 100 endorheic and riparian lagoons (tablas), occupying an area close to $250 \mathrm{~km}^{2}$. They are located in the middle of one of the driest regions in Spain. The tablas used to be and still are the home to very aquatic ecosystems with unique species of flora and fauna, and an important rest location for waterfowl migrating between Central Europe and North Africa. The most important wetland is Las Tablas de Daimiel (TD), a marshy area on the aquifer, covering up to $20 \mathrm{~km}^{2}$ under the previous undisturbed conditions. The TD is a national park. It was declared Reserve of the Biosphere by UNESCO in 1981. The Ojos del Guadiana (Guadiana Eyes) spring is the main outlet of the WLMA. Natural discharge was about $80-100 \mathrm{hm}^{3} /$ year. This spring area was considered by locals as the re-birth of the upper stretches of the Guadiana River after its base flow disappeared when entering the plain, downstream Peñarroya dam.

The 65-year average precipitation of the entire basin is around $400 \mathrm{~mm} /$ year, ranging from less than $200 \mathrm{~mm} / \mathrm{year}$ in dry sequences more than 10 year-long, to over $600 \mathrm{~mm} /$ year. Aquifer recharge in most of the driest years is practically zero. Between 1931 and 1971, the total runoff collected in the Vicario dam reservoir, at the outlet of the Upper Guadiana Basin, was 300-400 $\mathrm{hm}^{3} /$ year, equivalent to 20-25 mm/year. The Cigüela, Záncara, and Azuer are the main tributary rivers. Moderate flow peaks are produced 
Fig. 1 Castilla-La Mancha Region showing the location of the Western La Mancha Aquifer (WLMA) and the Eastern La Mancha Aquifer (ELMA). The geographic center of the figure lies at $39^{\circ} 17^{\prime} \mathrm{N}$ and $2^{\circ} 48^{\prime} \mathrm{W} . Z R$ Záncara River, $E P$ Peñarrolla dam, $E V$ El Vicario dam

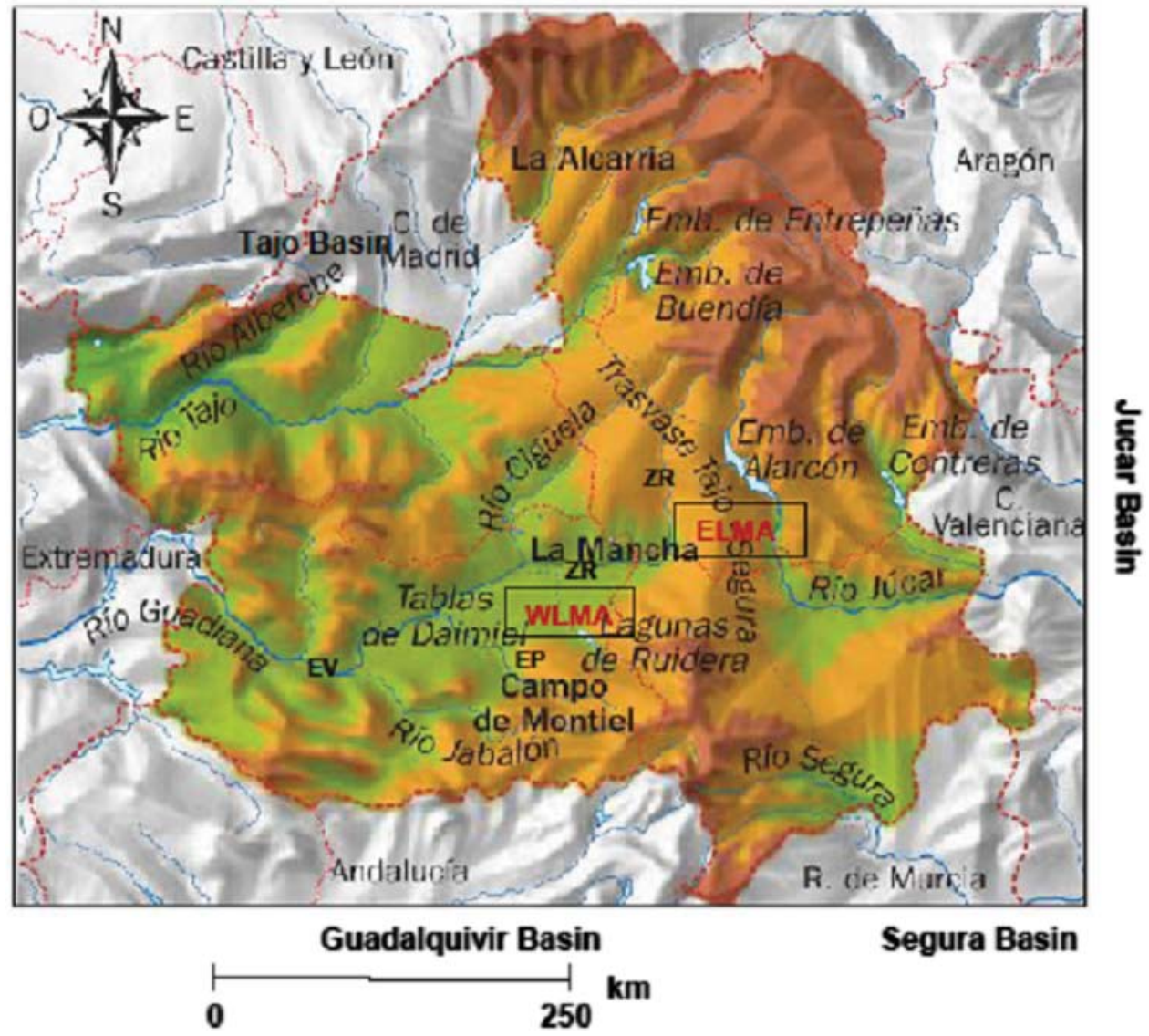

water imported from the Tajo-Segura aqueduct (a large water transfer canal that crosses the area) in some dry years since 1988 was partly a failure. Neither the hydroperiod nor the water quality was respected. The drainage of other valuable wetlands produced by the new channels affected a surface area which was larger than that of the wetlands to be restored (De la Hera A 1998; Martínez-Santos et al. 2008). A further problem was that the extreme water scarcity since the mid-1980s drained and dried the ground, so the peat formations existing in some areas started burning spontaneously. The combination of cracks and combustion in wetlands has produced an irreversible degradation process.

The period of 1995-1997 was exceptionally humid, with an estimated $800 \mathrm{hm}^{3}$ of recharge to the aquifer. This caused some recovery of the aquifer and wetlands, including the TD. Heavy rains were produced at the end of 2009 , followed by a wet period during the following years. Aquifer reserves in the period 2009-2011 increased by $1600 \mathrm{hm}^{3}$. Rivers returned to flow, combustion at peat areas ceased, and the wetland was filled with water. However, this is a transient condition. True recovery is much slower, as it happens currently. Partial wetland recovery, which will last several decades, would imply limiting water resources used for agriculture to between 100 and $200 \mathrm{hm}^{3} /$ year. 
The Guadiana River Basin Agency declared provisionally overexploited the aquifer in 1987 and formally in December 1994. The European Union approved a $100 \mathrm{M} €$ aid from 1993 to 1997, for farmers in the WLMA to stop irrigation. However, this did not reduce the planned pumping, the drilling of illegal wells continued, and groundwater reserves decreased about $4000 \mathrm{hm}^{3}$.

In the fall of 2009, 21 wells were constructed in the Guadiana and Cigüela river channels to artificially increase inflow into the TD, with an injection capacity of $2 \mathrm{~m}^{3} / \mathrm{s}$. Until present (spring 2016), it has not been necessary to operate them except to keep wells operational, so some recharge is been done.

Currently, the TD wetland behaves like a huge artificial recharge pond after being flooded in the very wet sequences by the Cigüela River runoff or by flows derived from the Tajo-Segura aqueduct.

In 1978, The Public Works Geological Service constructed a simplified groundwater numerical flow model to obtain quick responses on possible alternatives to reduce pumping from the aquifer (Sahuquillo et al. 1982), which was followed by a more detailed MODFLOW model (Cruces and Martínez-Cortina 2000). The authors concluded that the economic activity linked to irrigation was not at risk and most wetlands can be preserved without conflict with the farmers, if available water resources are used adequately and important changes in the water administration and in the attitude of the farmers are introduced. However, approaching the limit of water use in a dry area is risky, due to the large climatic fluctuations and water balance terms uncertainty.

\section{The Eastern La Mancha aquifer system (ELMA) and the Jucar River headwaters}

The Eastern La Mancha aquifer is the largest carbonate aquifer in the Iberian Peninsula, covering $7300 \mathrm{~km}^{2}$ in the upper Júcar River basin.

Since the late 1970s, the exploitation of the ELMA increased significantly with the irrigation of 100,000 ha. Aquifer abstraction grew to above $400 \mathrm{hm}^{3} /$ year during the 1990s (Ferrer and Gullón 2004). This resulted in continuous groundwater level drop and reduction of discharge to the Júcar River. Most river water between Alarcón Dam and Cabriel River comes from the aquifer. The permanent small rivers in the south-western area infiltrate into the aquifer at the entry of La Mancha. Groundwater recharge varies widely from dry to wet years, but the large groundwater storage damps outflow variations. Average flow has been quite accurately determined. Estimated aquifer recharge is $320 \mathrm{hm}^{3} /$ year (CHJ 2015). In this area, there are not significant wetlands and only a relatively small groundwater outflow to the Cabriel River. Flow exchange between the ELMA and the neighbouring WLMA seems small, but it is uncertain.

The 1980 drought reduced aquifer recharge and the Júcar River flow. Water level lowering disconnected the river and the aquifer along $20 \mathrm{~km}$ downstream from its previous position, before intensive pumping started (Fig. 2).

Figure 3 shows runoff caption by pumping, obtained as the difference between the estimated non-influenced runoff and gauged values. Volumes abstracted for meeting irrigation and drinking water needs rose from $140 \mathrm{hm}^{3}$ in 1982 to $377 \mathrm{hm}^{3}$ in 1996 and to $433 \mathrm{hm}^{3}$ in 2000 . In 2001,
Fig. 2 Profile along the Jucar riverbed and groundwater heads (Sanz et al. 2011)

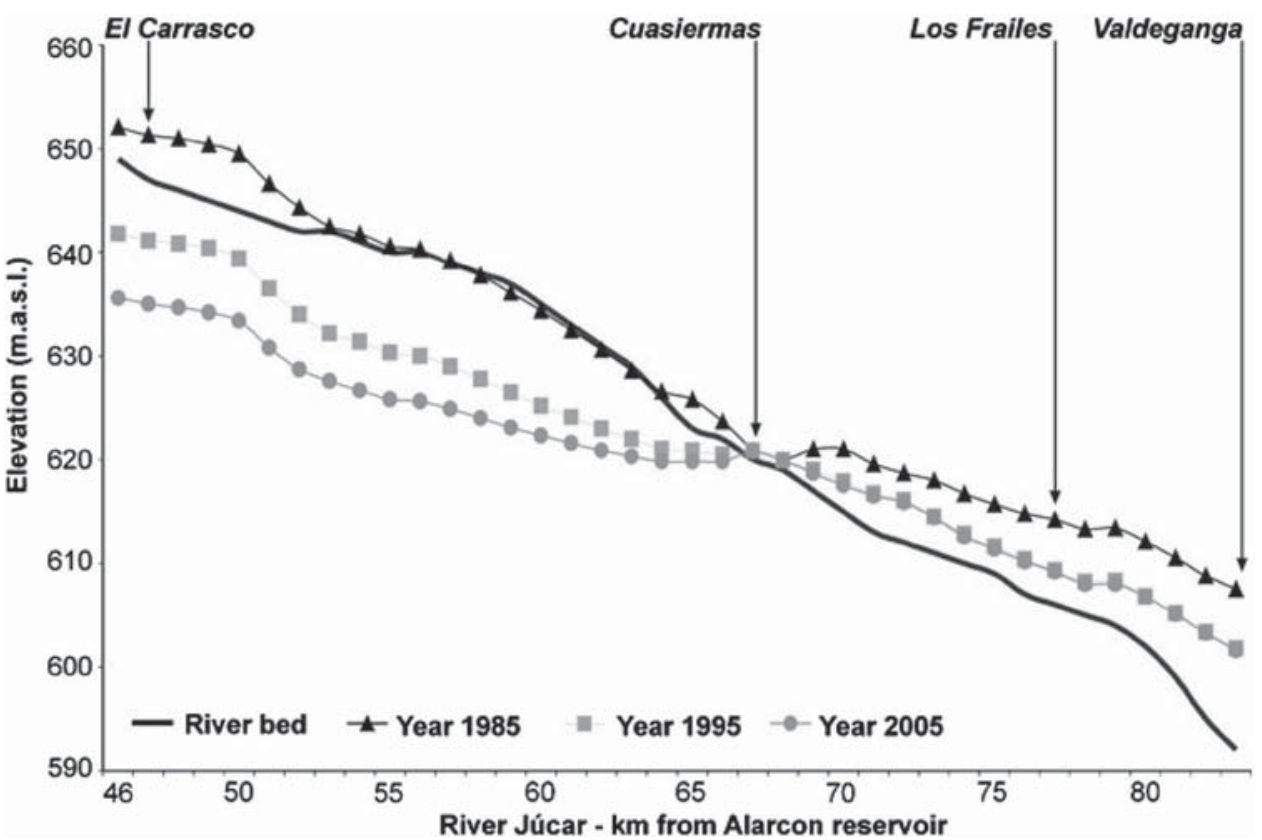


Fig. 3 Natural and altered annual streamflows in the Jucar River between the Alarcón and Molinar reservoirs (entrance and outlet of the Júcar River stretch in La Mancha área), and pumping-induced stream depletion (Perez-Martin et al. 2014)

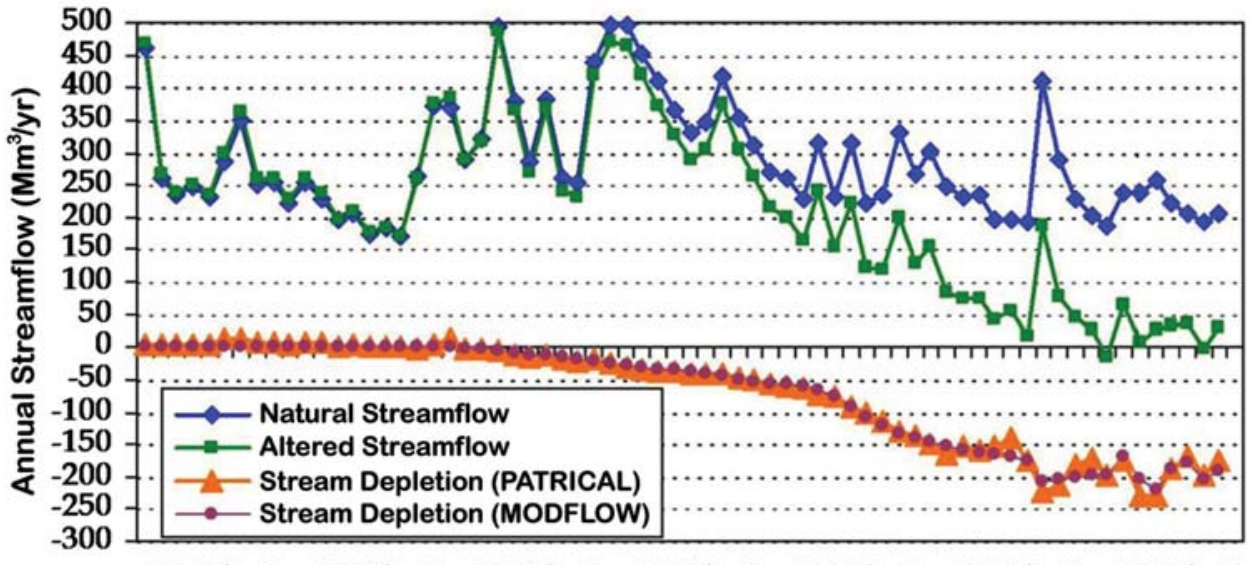

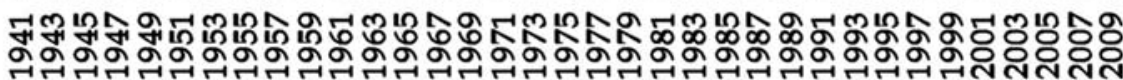

abstraction decreased in a sector due to groundwater substitution by surface water from the Tajo-Segura Aqueduct. In 2003, the city of Albacete began using surface water for supply. The cumulated storage depletion in 2005 was $3000 \mathrm{hm}^{3}$. In September 2006, the water stored in the large Alarcon and the other surface water reservoirs in the basin was short and little water flowed along the river due to the serious previous drought. It was a critical situation in the Júcar River basin. Then, the Júcar Water Agency tried to reduce aquifer pumping to meet supply water demands, with the cooperation of water users. A detailed 3D groundwater flow model with MODFLOW was calibrated considering carefully the aquifer-river interactions (Sanz et al. 2011). The Júcar Basin Authority announced a public tender to compensate farmers who irrigated in the previous 3 years and willing to transfer temporally water rights to reduce groundwater use. A cropping plan was developed. The board of irrigators agreed a $20 \%$ reduction in the whole aquifer abstraction. As only a part of the irrigation wells were close to the river, many of them would not be able to produce a significant effect on river flow during the irrigation period. To take this into account, the well detraction pattern was determined with the groundwater model. This was the basis for evaluating economic compensation to involved farmers during 2006-2007. To control pumped volumes in wells, GIS tools were used to cross the estimated volumes of water used after a remote sensing survey with the locations of existing wells, supported by a field survey.

The successful implementation of groundwater controls in ELMA during the last decade reduced abstraction to $300 \mathrm{hm}^{3} /$ year (Esteban and Albiac 2011, 2012).

Droughts and water depletion of the Eastern La Mancha aquifer are producing and triggering negative impacts in the middle and lower Júcar basin (CHJ 2015), mostly economic ones. Water available to the downstream users has been reduced and water demand for irrigation has increased in the last 40 years. In addition, improvements in the irrigation network increased efficiency, so the decreasing return flows from the irrigation districts have caused environmental concerns to the coastal Albufera wetland, near Valencia. The Albufera is the main aquatic ecosystem in the coastal area of the Júcar River, which is currently mostly fed by these return flows to the aquifer (García-Molla et al. 2013). To alleviate drought effects in the downstream Valencia coastal plain, the Júcar Water Agency (JBA) pumped $50 \mathrm{hm}^{3}$ of water from 65 local "drought wells" aquifer during the drought episode of 2006-2007.

\section{Water policy results in La Mancha}

Water policy results are mostly drawn from Kahil et al. (2015, 2016a, 2016b) and Esteban and Albiac (2011, 2012).

The management outcomes from the La Mancha aquifers show that the ELMA is moving towards sustainable management, while the neighbouring WLMA continues to be mismanaged. The empirical evidence seems to indicate that policies that are purely based on command and control (top-down) and economic instruments have failed in the WLMA, whilst policies based mostly on institutional instruments have improved water management in the ELMA. The attitudes of the WLMA farmers' representatives and the Water Authorities have been opposed: rejection versus cooperation, although rejection started to change toward cooperation when involved people have been water and farming experts instead of lawyers and administrators.

The institutional and policy developments in both aquifers contribute to explaining the management situation. The WLMA has had a strong increase in irrigated agriculture over the last 35 years, from 30,000 to 190,000 ha, of which 
50,000 ha are unregistered or using non-authorized groundwater flows. The the basin authority reaction to this rapid degradation was to declare the aquifer "officially" overexploited in 1987. However, it took 4 years for the basin authority to draft a plan to curb extractions applying a water quota system. It was completely ignored by farmers. A lobby to support illegal pumping was created by farmers' unions, municipalities, water user associations, and even members of the Region's Government.

During the 1990s, the so-called "Wetlands Plan" distributed $250 \mathrm{M} €$ to reduce extractions. However, the program failed to stop further water table drawdown. The efforts of the basin authority in 2005 to take illegal pumping to courts failed, because the Government of Spain yielded to pressures from farmers and the Region's Government. After that, the policy initiative was the Special Plan for the Upper Guadiana (CHGN 2008), aimed at curbing overdraft by pouring $5300 \mathrm{M} €$, mostly to buy groundwater rights. The plan was canceled in 2012. Abstraction controls did not exist. These huge investments would not be effective without carefully designed incentives to gain farmers' cooperation in reducing abstractions.

The ELMA experienced a similar increase of irrigation, from 20,000 to 100,000 ha over the last 35 years, fostering a substantial water table decline. Farmers became aware of the problems caused by aquifer depletion and responded by creating a water users' association in 1995, aimed at jointly managing the aquifer. The process began, because the Júcar Basin Agency called for the control of abstractions, threatening farmers by not issuing water use rights. Other reasons that gave rise to active support from farmers were the increase in pumping costs because of the fall of the aquifer water table, the increasing cost of energy, and the relatively small number of farmers involved when compared to other areas.

There was an agreement between the aquifer irrigation association, the Regional Government, and the Júcar Basin Agency to implement sustainable management. The agreement was based on the registration of water uses, characterization of water application, control of abstractions based on monitoring by remote sensing, and cultivation plans by each farmer. This system works, because farmers themselves are involved in the enforcement and control process. The efforts have resulted in a reduction in abstraction during the 2000 s from 400 to $300 \mathrm{hm}^{3} /$ year.

The facts presented above show the very different policy instruments that have been used in the WLMA and ELMA. In WLMA, the first type of policy instrument during the 1980s was command and control by forbidding new wells and establishing abstraction quotas. It failed because of the opposition of stakeholders. The second type of policy used was economic instruments: subsidies to farmers to reduce pumping and the more recent proposal of large investments, mostly to buy groundwater water rights from farmers. The large payments to farmers during the 1990s did not reduce abstractions and aquifer depletion increased. The huge investments from the Upper Guadiana Plan failed also to address the current mismanagement of the aquifer. The implication from this empirical evidence is that policies mostly based on command and control instruments and on economic instruments have failed in WLMA, while policies mostly based on institutional instruments have improved management of the ELMA.

However, other factors have to be considered to complete the picture. Really, in both places, institutional instruments have been applied, although with different intensity and development, according to the involved actors' interests. A key factor in reducing pumping in ELMA has been the strong pressure of the Júcar downstream farmers, who have water rights dating back centuries. The water scarcity problems mostly developed in the early 1980s, when groundwater was legally in the private domain. Therefore, the capacity of water authorities to act was limited. This did not change until the Water Act of 1985 was enacted. However, capabilities, trained personnel, experience on similar cases in large Spanish aquifers and in other countries, and even modelling capacity was short and had to be developed, but at the same time, the problems were cumulating. Technical capacity and internal resistance of old fashioned public servants were not a minor handicap.

In the Guadiana River, downstream El Vicario Dam, there were not significant river water users and ecological values had no champions. In the 1970s and 1980s, an association to defend irrigation and ecology (ADREDA) in the Daimiel area appeared, but this was a strange combination of two opposed orientations. The important river water users far downstream in the Guadiana River are not concerned as the water they receive mostly come from tributaries. The action in the WLMA was limited to try avoiding the drilling of new wells, which was opposed by farmers. Farmers were not fully aware of their own problems and interpreted public action as a non-justified interference on their rights.

Downstream, in the Júcar River, there are several important hydroelectricity plants, the Valencia City, the Albufera wetland, extensive irrigation areas, and other stakeholders that are directly affected and were actively involved in water problems from the beginning. The Water Authority was able to show the problems and get the collaboration of farmers and stakeholders as they were organized.

When economic instruments (water markets and water pricing) are compared with institutional instruments in the Júcar Basin, it results that during drought periods or water scarcity, the private profits of economic sectors are very close, either under water markets or under the current institutional setting (Kahil et al. 2015). However, water markets 
entail a reduction of water available to the environment compared with the institutional setting. Another important finding is that water pricing is a poor policy option, not only in terms of private and environmental benefits, but also in terms of equity.

\section{Brief comments on other Spanish cases}

Sustainability of groundwater development is a main concern in many intensively exploited aquifers in Spain. Only a brief mention is made of some ones, representing different circumstances. In some cases, action was previous to the incorporation of the European Water Framework Directive into the Spanish Water Act. Figure 4 shows the location of the different areas.

The Lower Llobregat aquifer system is a key water resource management element to the Metropolitan Area of Barcelona water supply (Custodio 2012b; Niñerola et al. 2009). It is a typical Mediterranean small coastal aquifer of $100 \mathrm{~km}^{2}$, holding $200 \mathrm{hm}^{3}$ of groundwater reserves at full capacity. Recharge depends mostly on river infiltration, return irrigation flows, and artificial action. Groundwater exploitation rate peaked at about $120 \mathrm{hm}^{3} / y e a r$ in the 1980s. Currently, it is $30-60 \mathrm{hm}^{3} /$ year. The turnover time is 3-4 years. In the delta area, seawater intrusion is a serious concern, although it is currently controlled. Management action started in the 1950s. The water supply system combines local and imported surface water, groundwater, enhanced and artificial aquifer recharge, desalination, and river salinity reduction wastewater reclamation. The role of the Lower Llobregat aquifer system shifted from a continuous water source for urban and industrial supply to mostly a reserve to complement summer water supply and to mitigate drought periods or river pollution incidents, after agreed management decisions. Groundwater levels in the main aquifer are currently below the river bed along the lower valley. Thus, the river recharges the aquifer all along the year, if low permeability sediments on the bed are naturally removed by floods or artificially scarified. Aquifer recharge is to some extent a managed variable decided by the Water Authority and the users. A very active groundwater users' association was created in 1975. As much of the water is for urban supply, besides quantity, water quality is important. It is protected by diverting saline water from the middle basin and corrected by advanced treatment. The cost of management is mostly paid indirectly by citizens and by industrial and services users through the water tariff, but not by farmers. Agriculture uses a moderate fraction of total water resources.

Currently, the Lower Llobregat aquifer system, through the management plan, is able to sustainably yield an average $60 \mathrm{hm}^{3} /$ year. Its value can be equated to $60 \mathrm{hm}^{3} /$ year capacity seawater desalination plant. Aquifer operation cost is about $0.25 € / \mathrm{m}^{3}$, which includes advanced water quality improvement. This cost is much less than the $0.70 € / \mathrm{m}^{3}$ operation costs of the desalination plant, when it is used at nominal capacity. However, the aquifer system needs facilities to restore and improve recharge and to limit seawater intrusion. The investment in recharge basins was about
Fig. 4 Location of the different considered areas in the Iberian Peninsula and in the Canary Islands. From NE to SW, the symbols mean: $L R$ Llobregat River; $L L$ Lower Llobregat area; CT Camp de Tarragona; ER Ebre/Ebro River; VR Vinalopó River basin; CT Campo de Cartagena; JR Júcar River; $L M$ La Mancha; GR Guadiana River; GVR Guadalquivir River; $D A$ Doñana area; LA Gran Canaria and Tenerife Islands. Notice that the Canary Islands are really placed $1500 \mathrm{~km}$ to the SW, in front of the Sahara's coast

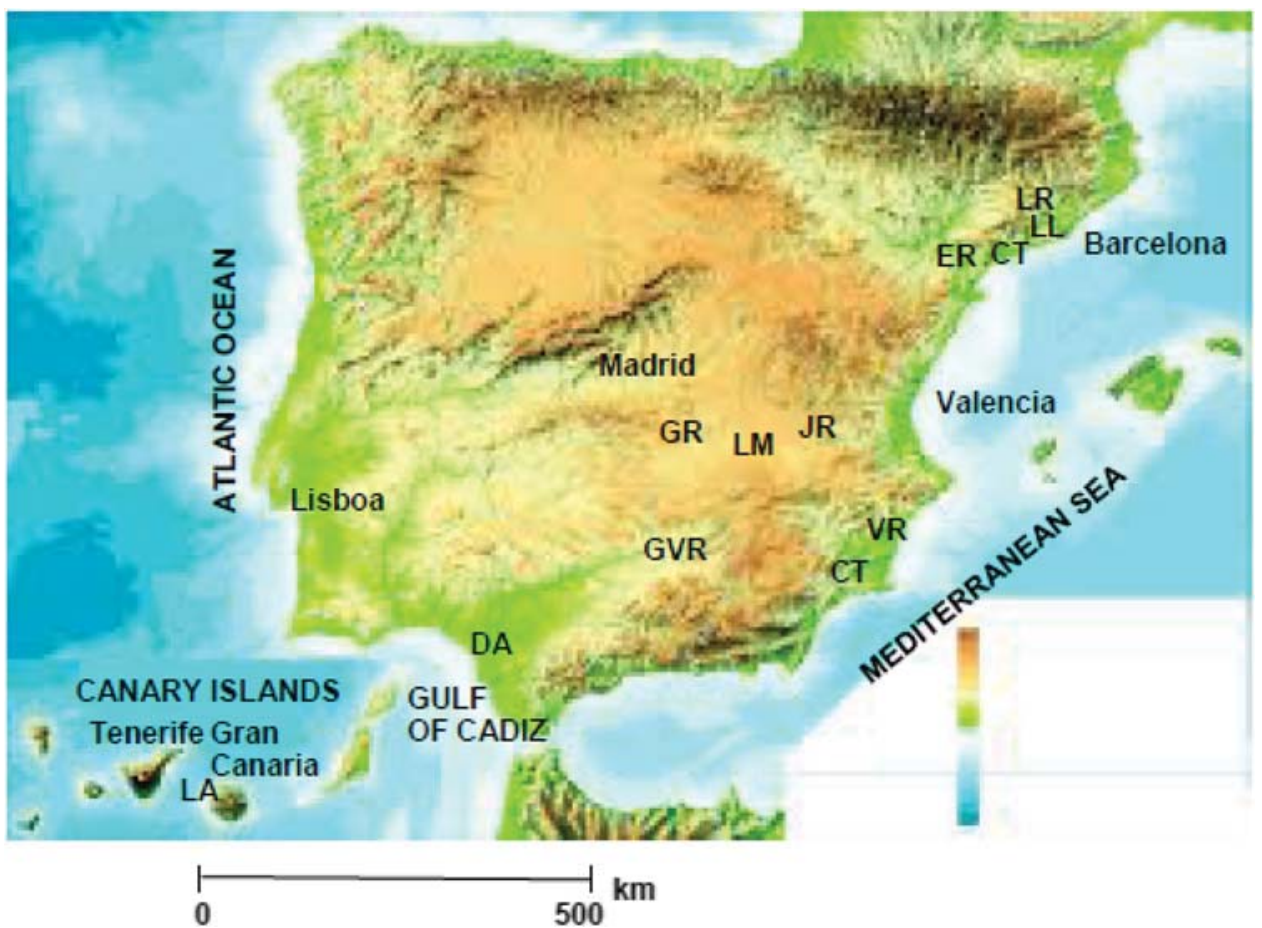


$15 \mathrm{M} €$. Operation cost varies between 0.03 and $0.15 € / \mathrm{m}^{3}$ for the recharge basins, is about $0.03 € / \mathrm{m}^{3}$ for river bed scarification, and 0.15 to $0.25 € / \mathrm{m}^{3}$ for injection of treated river water in wells. To limit seawater intrusion into the deep aquifer system layers, a coastal hydraulic barrier was constructed, injecting carefully treated reclaimed urban waste water. The investment was $23 \mathrm{M} €$ and operation at $15,000 \mathrm{~m}^{3} /$ day capacity costs about $0.2 € / \mathrm{m}^{3}$.

In the Camp de Tarragona, in the 1970s and 1980s, the aquifer system use was unsustainable, due to excessive uncontrolled abstraction. Further to the important and increasing groundwater head drawdown, seawater intrusion affected large areas. Privately abstracted groundwater was sold mostly to the industrial and oil refinery area. At the same time, urban supply was deteriorating, suffering from scarcity and excessive salinity due to sea water intrusion. Noticeable conflicts appeared among neighbouring municipalities. The transfer in 1981 of up to $2 \mathrm{hm}^{3} /$ year of surface water from the Lower Ebre river area, about $80 \mathrm{~km}$ to the $\mathrm{S}$, solved the problem. Heads recovered, seawater intrusion in coastal formations ceased, and salinized deep wells were shut down and recovered slowly afterwards. During the critical years, urban supply water was often brackish and only usable for sanitation. This was a serious social problem, but also a costly one as people was forced to use bottled water supply for drinking and cooking, and the life of domestic and industrial appliances was dramatically shortened.

In south-eastern Spain, intensive and mining groundwater development is a common fact (MASE 2015; Custodio et al. 2016b). This favoured quite an important economic and social development of the area through intensively irrigated cash-crops, although most situations are unsustainable in the mid-term. Remaining groundwater reserves are important for the transition toward a new and needed water use paradigm. Seawater desalination plants are available, although a small fraction of installed capacity is used due to the high cost of produced water. Urban waste water is tertiary treated and a large part of it is reclaimed for irrigation. The current application of direct and indirect subsidies to foster the use of this industrially produced water is not economically sustainable. Non-structural management actions are scarce to avoid the social problems derived from top-down decisions. The transition toward new water use paradigms is delayed by social and administrative inertia and pressure from water right holders, the well-developed markets for the agricultural products, and short-minded investors. The area is not homogeneous, so each problem needs a specific solution at local level. Pressure to attain the good quantitative and qualitative status of the aquifers, following the European Water Framework Directive, creates some socially difficult and costly situations. This is the case of the High and Mid Vinalopó river basin, where to halt groundwater mining and get an equilibrated water balance, about half of the current groundwater abstraction for irrigation and supply, at a cost of about $0.3-0.4 € / \mathrm{m}^{3}$, will be substituted by highly subsidized imported water from the Lower Jucar, whose true total cost in the area is above $1 € / \mathrm{m}^{3}$. This high cost is due to an elevation of about $700 \mathrm{~m}$ and the mixing with desalinated water to improve the poor quality of the water to be transferred. This aquifer management action is technically sound, but it is not economically and socially sustainable. It is a political decision. Correction needs a change of water use paradigm.

The Campo de Cartagena is an important irrigated agricultural coastal area. The high pressure on the aquifer has been tamed by surface water transfer from outside, but it is variable from year to year and subjected to approval by the Government of Spain each time. In dry years, the transfer may fail. Then, the aquifer complements the water deficit, thus further compromising its sustainable use (Senent and García-Aróstegui 2013). Groundwater is often brackish and deteriorating. This is largely due to return irrigation flows. To reduce salinity, a large number of small de-brackishing plants are in operation. Something similar happens in the Campo de Níjar. In both areas, irrigation water applied is often a calculated mix of groundwater with other more expensive water sources. Even if the aquifers attain a sustainable use from the point of view of water quantity, it will be not from the point of view of water quality.

The Campo de Dalías is a highly yielding agricultural area. In the $300 \mathrm{~km}^{2}$ of surface area, $200 \mathrm{~km}^{2}$ are intensively cultivated under plastic and in greenhouses, using $120 \mathrm{hm}^{3} /$ year of groundwater. Production value is about $3000 \mathrm{M} €$ at market prices. This semiarid area has a rather good aquifer recharge transferred from the neighbouring Sierra de Gádor. Current groundwater abstraction is twice the estimated recharge. Therefore, there is an increasing groundwater head drawdown in the deep, high yielding aquifers, which suffer saline water intrusion in large areas. At the same time, that the deep aquifer groundwater head decreases, the water table aquifers, poor water quality, and rather high salinity are being recharged mostly by return irrigation flows. Besides inundation problems created by an expanding lagoon area, there is a large storage of water which is not suitable for irrigation but that can be de-brackished at affordable prices.

In the Campo de Cartagena, Campo de Dalías, and other areas in south-eastern Spain, the cost of obtaining groundwater is 0.20 to $0.40 € / \mathrm{m}^{3}$. Intensive agriculture using improved irrigation methods or under greenhouses produces about $2000 \mathrm{M} € /$ year. Water productivity is $2-4 € / \mathrm{m}^{3}$, leaving a net margin to the farmer of $0.2-2.0 € / \mathrm{m}^{3}$, depending on crop and labour costs. A golf course yields about $1.3 € / \mathrm{m}^{3}$ (references in MASE 2015). Mid-term hydrologic and economic sustainability is difficult to address from 
public institutions. It may be attained through groundwater users' institutions and a careful economic management of the situation. Several groundwater users' associations exist, mostly to deal with internal affairs and protect their rights, but there is the potential to expand them, as commercial associations are well developed. Abstraction reduction and a change in water use paradigm are needed.

The Doñana Area, in SW peninsular Spain, contains important wetlands. It is the largest natural area in Western Europe (Custodio et al. 1999, 2008). On the sandy aquifer system and its fringe areas (ecotones) with the large surface water marsh, hundreds of small lagoons and cryptowetlands develop. An important irrigated agricultural development took place in the early 1980s, using local deep groundwater. Consequently, the natural system functioning has notably been modified. As groundwater abstraction is less than recharge if a given level of groundwater exploitation is maintained, a new average equilibrium state will be reached, but decreasing local stream flow and the number and surface area of wetlands, changing the hydro-period, and desiccating part of the ecotones and small rivulets. The transient stage lasts several decades. Until present, good governance has been an elusive goal due to poor understanding of the real problem by stakeholders and decision-makers, ineffective institutions, top-down uncertain action of the Water Authority, reluctance of groundwater users, and a quite important number of illegal groundwater abstractions. Even if current exploitation and groundwater use are frozen, changes will go on for decades except at local level. As the groundwater system recovery time is about 60 years, his discourages politicians to carry out remediation. Long-term, clearly defined goals and perdurable institutions and regulations are needed, which have to be agreed by society and authorities. Progress appears tricky as there is no real will to look for win-win solutions but pre-established ones.

In the volcanic Canary Islands, circumstances are highly variable. Climate varies from arid in the coast to semihumid in part of the highlands. Currently, groundwater is mostly developed by means of long galleries (tunnels), large diameter excavated wells with bottom drains (Canarian wells) and deep boreholes. The result is an inland important water table drawdown and seawater contamination in some of the recent coastal volcanic formations (Custodio and Cabrera 2013). Current groundwater development in the two most populated and economically significant islands, Gran Canaria and Tenerife, is non-sustainable even if abstraction is less than recharge. This is due to the unavoidable large discharge of groundwater to the sea. Groundwater trading and markets are operating, which currently also incorporate desalinated seawater since the 1960s and reclaimed waste water since the 1970s (MASE 2015; Custodio et al. 2016a). The deals in the water markets in
Gran Canaria amount to about 25 and $50 \mathrm{M} € /$ year in Tenerife. When the cost of making the water available to the site of use is considered, the direct cost of providing groundwater for intensive crop irrigation is often less than the partly subsidized price of industrial water resources. Longterm aquifer sustainable use needs abstraction reduction. In some inner areas of Gran Canaria, this is happening due to the high cost of pumping water. As in Tenerife, a large part of abstraction is by means of middle and high altitude galleries, whose yield is decreasing, a shift to more use of wells is needed.

\section{Conclusions}

Sustainability as synonymous of durable has no meaning in a continuously changing world. Physical and hydrological changes are important, but they are overpassed by the fastevolving economic and social conditions. Therefore, a reference state cannot be chosen. Some decades ago, the current importance of ecology and ecological services was not suspected. Therefore, some future trends and new priorities are not easy to forecast if possible at all. This affects how sustainability is defined and the role of groundwater.

Water availability in the mid and long terms is a relevant issue as it is a non-replaceable good for human life, but also for ecosystems, human well-being, and economic activities that sustain the social framework. However, the use, demand, and consumption of water are also changing. The future pattern may be quite different from the current one. Economic and environmental considerations of future outcomes through sound scenario assessment are important, especially when accounting for the possible global and climate change impacts.

Aquifer development sustainability in arid and semiarid areas is currently dominated by water quantity aspects (volume, flow). Besides, other aspects have to be considered, often with an increasing weight, such as water quality, and economic and social implications, including in them ethical and moral considerations. To consider water quality issues, extensive parallel works are needed (Custodio 2013). Groundwater salinization and contamination with nutrients is a worldwide problem, not only in coastal environments but as the result of arid climate, lithological influence and irrigation return flows, and recently the unsafe disposal of desalination and de-brackishing back-flows.

Aquifer sustainability is not a purely scientific and technical issue but the result of social decisions that involve human use and well-being, ecology and ecological services, economic benefits and costs, social preferences and needs, and finally political decisions and reliable implementation. The intrinsic mid- and long-term viewpoints have to be combined with the short-time political behaviour 
and the solution of current pressing problems. Each case has its own characteristics. A general pattern does not exist, although common features can be pointed out. Local considerations are important and should be taken into account through the subsidiarity principle, promoting the collective action of stakeholders. Governmental, social, scientific, and water user's institutions are key components of the needed cooperation. All this shapes good water governance, which includes management and planning. This is the right place to define aquifer development sustainability. Due consideration of uncertainty has to be included and evaluated, taking into account the relevance of each particular situation.

Groundwater quantity resources are often erroneously equated to recharge. Recharge estimation has to refer to actual conditions. In many cases, it is not an aquifer property but a dependent magnitude. Aquifer sustainable abstraction is often much less than recharge. However, it can be greater if groundwater reserve depletion (mining) is done for a limited time. This may be sound considering water resources integration and the evolution toward a new water use paradigm.

Sustainable aquifer development, in the sense of durability, loses its meaning when integrated water resources management is considered. The role of aquifers changes from a permanent source of water to storage to solve or tame time evolution, if the related ecological values are taken into account.

Some interesting learning can be obtained from the La Mancha and the other examples. They show the importance of local circumstances and that no one type of policy instrument is superior to the others for sustainable water management under all circumstances. In fact, some authors warn against the use of a single type of policy instrument for solving water management problems (Ostrom et al. 2007). Water markets and stakeholders' cooperation are alternative approaches to achieve welfare gains in the form of private and social benefits. Both approaches are intertwined. Water trading experiences worldwide indicate that pure markets tend to disregard third party effects, including environmental impacts. Well-functioning water markets would require a great deal of regulation or cooperation by stakeholders within a strong institutional setting. Conversely, in countries, such as Spain, the institutional approach would work better by using carefully designed economic instruments. Incentives would introduce more flexibility into the institutional process of decision-making and implementation, but they have to be carefully designed for each case, under clearly stated conditions, for a limited period of time and subjected to periodical analysis of their efficacy.

Acknowledgements Part of the knowledge and data have been derived from the MASE (2015) and the on-going SASMIE (Groundwater salinization in Spanish Mediterranean and island coastal aquifers) projects, carried out by the Department of Civil and Environmental Engineering of the Technical University of Catalonia (UPC), with economic support of SUEZ Advanced Solutions (AQUALOGY) and guidance of Cetaqua. Dr. L. Martinez Cortina provided information and data on the Western La Mancha Aquifer.

\section{References}

ASCE (1961) Groundwater basin management. Manuals and reports on engineering practice 40. Am Soc Civil Eng, Washington

Bear J, Levin O (1967) The optimal yield of an aquifer. In: Symposium on artificial recharge and management of aquifers, Haifa. IAHS-UNESCO, Publ, vol 72, pp 401-412

Bocanegra E, Manzano M, Custodio E, Cardoso da Silva G, Betancur $\mathrm{T}$ (2016) Comparing management actions in groundwater related wetlands with significant services to human welfare in IberoAmerica. Episodes 39(1):19-38

Booker J, Howitt R, Michelsen A, Young R (2012) Economics and the modeling of water resources and policies. Nat Res Model 25(1):168-218

Camacho A, Russi D, Custodio E, Manzano M (2015) Assessment and valuation of wetlands services for their consideration into decision-making. In: Management and protection of groundwater related coastal wetlands and their services. Regional Report. UNEP-UNESCO, Paris

CHGN (2008) Plan Especial del Alto Guadiana [Special Plan of the Upper Guadiana]. Confederación Hidrográfica del Guadiana, Badajoz

CHJ (2015) Plan Hidrológico de Cuenca de la Demarcación Hidrográfica del Júcar, ciclo 2015-2021 [Water Plan of the Júcar Water District, 2015-2021 cycle]. Confederación Hidrográfica del Júcar, Valencia. http://www.chj.es/es-es/ciudadano/consultapublica/Paginas/PHC-2015-2021-PlanHidrologicodecuenca. aspx. Accessed Oct 2015

Conkling H (1946) Utilization of groundwater storage in stream system development. Trans Am Soc Civil Eng 111:523-540

Cruces J, Martínez L (2000) La Mancha Húmeda: Explotación intensiva de las aguas subterráneas en la cuenca alta del río Guadiana [Intensive groundwater exploitation in the upper Guadiana basin]. Papeles del Proyecto Aguas Subterráneas, Fundación Marcelino Botín, Madrid

Custodio E (1976) Recursos y reservas de agua subterránea: problemática general [Groundwater resources and reserves: general aspects]. In: Custodio E, Llamas M (eds) Hidrología Subterránea. Ediciones Omega, Barcelona, pp 2257-2266

Custodio E (2002) Aquifer overexploitation, what does it mean? Hydrogeol J 10(2):254-277

Custodio E (2012a) Intensive groundwater development: a water cycle transformation, a social revolution, a management challenge. In: Martínez L, Garrido A, López-Gunn E (eds) Rethinking water and food security. CRC, Boca Raton, pp 259-298

Custodio E (2012b) Low Llobregat aquifers: intensive development, salinization, contamination and management. In: Sabater S, Ginebreda A, Barcelo D (eds) The Llobregat. The story of a polluted Mediterranean River, the handbook of environmental chemistry 21. Springer, Heidelberg, pp 27-50

Custodio E (2013) Trends in groundwater pollution: loss of groundwater quality \& related services. Groundwater Governance: a Global Framework for Action, GEF-World Bank-UNESCO http://www.groundwatergovernance.org/fileadmin/user_upload/ groundwatergovernance/docs/Themat

Custodio E, Cabrera M (2013) The Canary Islands. In: De Stefano L, Llamas M (eds) Water, agriculture and the environment in Spain, can we square the circle? CRC, Boca Raton, pp 281-290 
Custodio E, Manzano M, Montes C (1999) Las aguas subterráneas en Doñana: aspectos ecológicos y sociales. [Groundwater in Doñana: ecological and social aspects]. Agencia Andaluza del Agua. Consejería de Medio Ambiente. Junta de Andalucía, Sevilla

Custodio E, Manzano M, Montes C (2008) Perspectiva general del papel y gestión de las aguas subterráneas en el área de Doñana, Sudoeste de España. [General view of groundwater role and management in the Doñana area]. Boletín Geológico y Minero 119(1):81-92

Custodio E, Cabrera M, Poncela R, Cruz T, Naranjo G, Puga L (2015) Comments on uncertainty in groundwater governance in the volcanic Canary Islands, Spain. Water 7(6):2952-2970

Custodio E, Cabrera M, Poncela R, Skupien E, Del Villar A (2016a) Groundwater intensive exploitation and mining in Gran Canaria and Tenerife Islands, Canary Islands, Spain: hydrogeological, environmental, economic and social aspects. Sci Total Environ 557-558:425-437

Custodio E, Andreu J, Aragón R, Estrela T, Ferrer J, García J, Manzano M, Rodríguez L, Sahuquillo A, del Villar A (2016b) Groundwater intensive use and mining in south-eastern peninsular Spain: hydrogeological, economic and social aspects. Sci Total Environ 559:302-316

De la Hera A (1998) Análisis hidrológico de los humedales de la "Mancha Húmeda" y propuesta de restauración de un humedal ribereño: El Vadancho (Toledo) [Hydrological analysis of the "Wet Mancha" and restoration proposal of a riparian wetland: El Vadancho (Toledo)]. Dissertation, Complutense University of Madrid

De la Hera A, Villarroya F (2013) Services evolution of two groundwater dependent wetland ecosystems in the "Mancha Húmeda" biosphere reserve (Spain). Resources 2:128-150

De la Hera A, Gurrieri J, Puri S, Custodio E, Manzano M (2016) Ecohydrology and hydrogeological processes: groundwater-ecosystem interactions with special emphasis on abiotic processes. Ecohydrology Hydrobiology 16(2):99-105

EC (2012) Communication from the Commission to the European Parliament, the Council, the European Economic and Social Committee and the Committee of the Regions. A Blueprint to Safeguard Europe's Water Resources, COM (2012) 673 final. European Commission, Brussels

Esteban E, Albiac J (2011) Groundwater and ecosystems damages: questioning the Gisser-Sánchez effect. Ecol Econ 70:2062-2069

Esteban E, Albiac J (2012) The problem of sustainable groundwater management: the case of La Mancha aquifers, Spain. Hydrogeol J 20(5):851-863

Feinerman E, Knapp K (1983) Benefits from groundwater management: magnitude, sensitivity, and distribution. Am J Agr Economics 65(4):703-710

Ferrer J, Gullón N (2004) Actuaciones de gestión y regularización administrativa en el acuífero de La Mancha Oriental [Management and regulation action in the Western La Mancha aquifer]. VII Simposio de Hidrogeología, Zaragoza. Hidrogeología y Aguas Subterráneas XXVII:423-432

García-Molla M, Sanchis C, Ortega M, Avella L (2013) Irrigation associations coping with drought: The case of four irrigation districts in Eastern Spain. In: Schwabe K, Albiac J, Connor J, Hassan R, Meza L (ed) Drought in arid and semi-arid environments: a multi-disciplinary and cross-country perspective. Springer, Dordrecht, pp 101-122

Kahil M, Dinar A, Albiac J (2015) Modeling water scarcity and droughts for policy adaptation to climate change in arid and semiarid regions. J Hydrol 522:95-109

Kahil M, Albiac J, Dinar A, Calvo E, Esteban E, Avella L, GarcíaMolla M (2016a) Improving the performance of water policies: evidence from drought in Spain. Water 8(2):1-15
Kahil M, Ward F, Albiac J, Eggleston J, Sanz D (2016b) Hydroeconomic modeling with aquifer-river interactions to guide sustainable basin management. J Hydrol 539:510-524

Konikow L, Leake S (2014) Depletion and capture: revisiting the source of water derived from wells. Ground Water 52(1):100-111

López-Gunn E, Llamas M, Garrido A, Sanz D (2011) Groundwater management. In: Wildever P (ed) Treatise on water science. Elsevier, New York, pp 97-127

Manzano M, Camacho A, Custodio E, de la Hera A (2015) Main hydro(geo)logical characteristics, ecosystem services, and drivers of change of 26 representative Mediterranean groundwater-related coastal wetlands. Technical Report for UNEP-UNESCO. http://unesdoc.unesco.org/ images/0023/002352/235228e.pdf

Martínez-Santos P, De Stefano L, Martínez-Alfaro PE, Llamas MR (2008) Wetland restoration in the Mancha Occidental aquifer, Spain: a critical perspective on water, agricultural and environmental policies. Restor Ecol 16(3):511-521

Martínez-Cortina L, Mejías Moreno M, Díaz Muñoz JA, Morales García R, Ruiz Hernández JM (2011) Cuantificación de recursos hídricos subterráneos en la cuenca alta del Guadiana. Consideraciones respecto a las definiciones de recursos renovables y disponibles [Water resources quantification in the upper Guadiana basin. Considerations on the definition of renewable and available resources]. Boletín Geológico y Minero 122(1):17-36

Martínez-Santos P, Aldaya MM, Llamas MR (2014) Integrated water resources management in the 21th century: revisiting the paradigm. Botín Foundation-CRC Press, Boca Raton, pp 1-311

MASE (2015) Aspectos hidrológicos, ambientales, económicos, sociales y éticos del consumo de reservas de agua subterrânea en España: minería del agua subterránea en España [Hydrological, environmental, economic, social and ethical aspects of groundwater reserve consumption in Spain: groundwater mining in Spain]. In: Custodio E (ed) Minería del Agua Subterránea en España, UPC and SUEZ Advanced Solutions (AQUALOGY)-Cetaqua, Barcelona. http://h2ogeo.upc.edu/es/ proyectos-empresa-ghs\#d\%C3\%A9cada-2010

Meinzer O (1920) Quantitative methods to estimating ground-water supplies. Bull Geol Soc Am 31:329-338

Molinero J, Custodio E, Sahuquillo A, Llamas M (2011) Groundwater in Spain: Legal framework and management issues. In: Findikakis A, Sato K (eds) Groundwater management practices. CRC, Boca Raton, pp 123-137

Niñerola J, Queralt E, Custodio E (2009) Llobregat delta aquifer. In: Quevauviller P, Fouillac A, Grath J, Ward R (eds) Groundwater monitoring. Wiley, New York, pp 289-301

Ostrom E (1990) Governing the commons: the evolution of institutions for collective action. Cambridge University Press, Cambridge

Ostrom E (2010) Beyond markets and states: polycentric governance of complex economic systems. Am. Econ Rev 100(3):641-672

Ostrom E, Janssen M, Anderies J (2007) Going beyond panaceas. Proc Nat Acad Sci 104(39):15176-15178

Pérez-Martín M, Estrela T, Andreu J, Ferrer J (2014) Modeling water resources and river-aquifer interaction in the Júcar River Basin, Spain. Water Resour Manag 28:4337-4358

Qureshi E, Reeson A, Reinelt P, Brozović N, Whitten S (2012) Factors determining the economic value of groundwater. Hydrogeol J 20:821-829

Richey A, Thomas B, Lo M, Reager J, Famigliettti J, Voss K, Swenson S, Rodell M (2015) Quantifying renewable groundwater stress with GRACE. Water Resour Res. doi:10.1002/201 5WR017349.

Rogers P, Llamas M, Martínez L (2004) Water crisis: myth or reality? Taylor \& Francis, London 
Sahuquillo A, Lopez J, Lopez B (1982) Transient simulation of an aquifer connected to a wetland ecosystem. Math Comput Simul XXIV:161-172

Sanz D, Castaño S, Cassiraga E, Sahuquillo A, Gómez J, Peña S, Calera A (2011) Modeling aquifer-river interactions under the influence of groundwater abstraction in the Mancha Oriental System (SE Spain). Hydrogeol J 19(2):475-487

Senent M, García-Aróstegui JL (2013) Sobreexplotación de acuíferos en la Cuenca del Segura: evaluación y perspectivas [Aquifer overexploitation in the Segura basin: evaluation and perspectives]. Fundación Instituto Euromediterráneo del Agua, Murcia, pp 1-234

Visscher W (1968) A brief study to evaluate the optimal groundwater withdrawal in a relatively large river basin in The Netherlands. General Assembly of Bern. Intern Assoc Sci Hydrol Publ 77:131-191

Young R (1970) Safe yield of aquifers: an economic reformulation. J Irrig Drain Div (ASCE) 96(IR-4):377-385 